\title{
DEFLECTION BEHAVIOUR OF SLAB PAVEMENT WITH PILE ON SOFT SOIL
}

\author{
Adolf Situmorang*
}

Ph.D Candidate, Universitas Islam Sultan Agung and Lecturer in Civil Engineering Faculty, Universitas Semarang, Jalan Sukarno Hatta, Central Java 50196, Indonesia

\section{Pratikso, Abdul Rochim}

Civil Engineering Department, Universitas Islam Sultan Agung, Jalan Raya Kaligawe, Central Java 50112, Indonesia

*Corresponding Author: situmorangadolf@usm.ac.id

\begin{abstract}
The existence of soft soil is one of the obstacles in building road infrastructure, where the carrying capacity of soft soil is very low and can create instability of a building above it, and this is still one of the serious problems that must be overcome. One solution to building a road over soft soil is by using the pavement with a glued plate system, this model is considered to be stronger when compared to the conventional [1] slab pavement system because the addition of piles as pavement anchor can increase the stability of the pavement because it can increase the bearing capacity of the pavement plate.

This research was carried out by an experimental test in the laboratory by making a prototype of slab pavement supported by piles. Applied lateral load is $1 \mathrm{kN}, 2 \mathrm{kN}$ and $4 \mathrm{kN}$ from modification vibrator machine. Other than the experimental test, in addition, finite element method analysis carried out, and compared the results of the experimental test.

The experimental results showed that an increase in lateral loading would increase the deflection of the slab pavement, for a lateral load of $1 \mathrm{kN}$ there was a deflection of $0.21 \mathrm{~mm}$ and an increase of $34 \%$ for loading of $2 \mathrm{kN}$ and an increase of $45 \%$ for loading $4 \mathrm{kN}$. The pattern is the same in the finite element method analysis, where there was a 9.3\% increase for $2 \mathrm{kN}$ loading and increased to $34 \%$ for $4 \mathrm{kN}$ loading.
\end{abstract}

Keywords: Soft Soil, Deflection of Slab, Pavement.

Cite this Article: Adolf Situmorang and Pratikso, Abdul Rochim, Deflection Behaviour of Slab Pavement with Pile on Soft Soil. International Journal of Civil Engineering and Technology, 11(2), 2020, 52-59.

https://iaeme.com/Home/issue/IJCIET?Volume $=11 \&$ Issue $=2$ 


\section{INTRODUCTION}

Soft soil is a separate issue that must be overcome when road construction will be built, and according [3] states that around 30\% of Indonesia's total of the land area is soft soil, with characteristics of low carrying capacity. Some of the solutions carried out in handling soft soil as highway foundations are the replacement of soil, soil stabilization, but this solution can have an impact on environmental. But in this research, the solution to improving soft soil as the base course of the road is making a new method of pavement with slab pavement or nailed slab system.

Nailed Slab System is one of the solutions for pavement above soft soil, this model the same as conventional rigid pavement, the difference is only in anchors or pile in the bottom slab. If we Compared to flexible pavement, the conventional rigid pavement is considered to be stronger in bearing the load above it because of its rigid nature, but is very weak if the conventional rigid pavement is carried out on subgrade with low bearing capacity because can cause cracks in the pavement layer, so that the addition of a pile or anchor in the bottom of pavement will be able to increase the stiffness of the pavement so that it is expected that damage or cracks on the pavement will not occur.

\section{METHODE OF RESEARCH}

Slab pavement with pile or nailed slab system as a substitute for conventional pavement [1], and this pavement consists of thin slab with a thickness about 10-15 cm supported by small piles with the length of pile about $1 \mathrm{~m}-1.5 \mathrm{~m}$ and diameter of pile $15-20 \mathrm{~cm}$, with the presence of this pile it is expected that the load can be channeled to the base layer until a depth of $1 \mathrm{~m}$ $1.5 \mathrm{~m}$ of soft soil and pile monolith with a slab pavement. But this research is an experimental study with dimensions and sizes that are different from previous research [4].

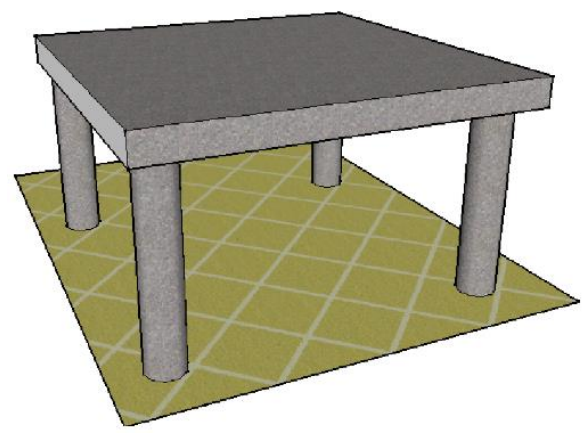

Figure 1 Three Dimensional Nailed Slab System

\subsection{Prototype and Instrumentation}

The monitoring instrument from the strain gauge is mounted on the slab pavement reinforcement and reinforcement of the pile and is connected to the data logger and directly monitored by the computer. After the installation of the monitoring instrument is carried out, casting is carried out with the quality of concrete f'c $21 \mathrm{MPa}$, the casting is carried out gradually from the pile to the slab pavement. The results of slab pavement and pile are ensured to be carried out properly without any cavities in the concrete. The stages of installation of monitoring systems on reinforcement and implementation of making slab pavement prototypes as shown in Fig. 2 

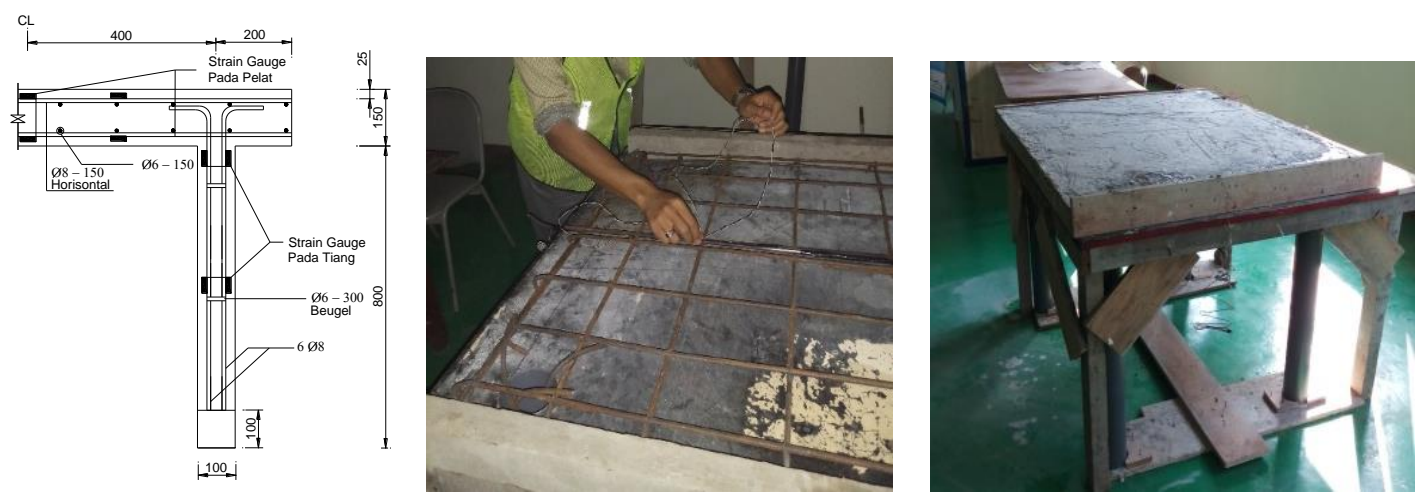

Figure 2 Install Strain Gauge

\subsection{Soil Properties and Sample Preparation}

The soil used in the test box is soil with characteristics as soft soil, as can be seen from the results of soil testing in Table 1. This soft soil will be used into the test box and compacted according to the level of density in the field, the stages in compaction in the test box are 20 $\mathrm{cm}$ per layer. Compaction is carried out to achieve the desired consolidation [2].

Table 1 Soft Soil Properties

\begin{tabular}{|c|c|c|c|}
\hline No & Parameter & Unit & Average \\
\hline 1 & Spesific Gravity, GS & - & 2,262 \\
\hline \multirow[t]{4}{*}{2} & Consistency Limits: & & \\
\hline & Liquid Limit, LL & $\%$ & 55,4 \\
\hline & Plastic Limit, PL & $\%$ & 10,07 \\
\hline & Plasticity Index, PI & $\%$ & 45,33 \\
\hline 3 & Water Content, w & $\%$ & 53,58 \\
\hline 4 & Bulk Density, $\gamma$ & $\mathrm{kN} / \mathrm{m}^{3}$ & 12 \\
\hline 5 & Dry Density, $\gamma_{d}$ & $\mathrm{kN} / \mathrm{m}^{3}$ & 16 \\
\hline \multirow[t]{3}{*}{6} & Direct Shear Test: & & \\
\hline & Cohession, c & $\mathrm{kN} / \mathrm{m}^{2}$ & 12,26 \\
\hline & Friction Angle, $\phi$ & deg & 9,3 \\
\hline 7 & $\mathrm{CBR}$ & $\%$ & 1,93 \\
\hline \multirow[t]{3}{*}{8} & Soil Clasification: & & \\
\hline & AASHTO & - & A-7-6 \\
\hline & USCS & - & $\mathrm{CH}$ \\
\hline
\end{tabular}

\subsection{Finite Element Method}

In the finite element method analysis, 3D Plaxis are used to determine changes and movements of pile and slab pavement. Geometry is simulated by means of an axisymmetric model in which the pile is positioned along the symmetry axis. Interface elements are placed around the stack of interaction models between stack and soil. The model boundaries are taken far enough away to avoid the influence of boundary conditions. Standard absorbent limits are used to avoid false reflections. The presence of groundwater level is ignored. Fig. 3 shows the slab pavement model.

Soil properties input plaxis: Modulus of concrete $(E)=3 \times 10^{7} \mathrm{kN} / \mathrm{m}^{2}$, Poisson's ratios of concrete $(\mu)=0.1$, Unit weight of concrete $\left(\gamma_{\mathrm{c}}\right)=25 \mathrm{kN} / \mathrm{m}^{3}$. The properties of soft clay are taken as $\gamma_{\text {unsat }}=12 \mathrm{kN} / \mathrm{m}^{3}, \gamma_{\mathrm{sat}}=16 \mathrm{kN} / \mathrm{m}^{3}, E_{\text {ref }}=15000 \mathrm{kN} / \mathrm{m}^{2}, R_{\text {inter }}=0.5, C=12,26 \mathrm{kN} / \mathrm{m}^{2}, \phi$ $=9,3, \mu=0,3$. 

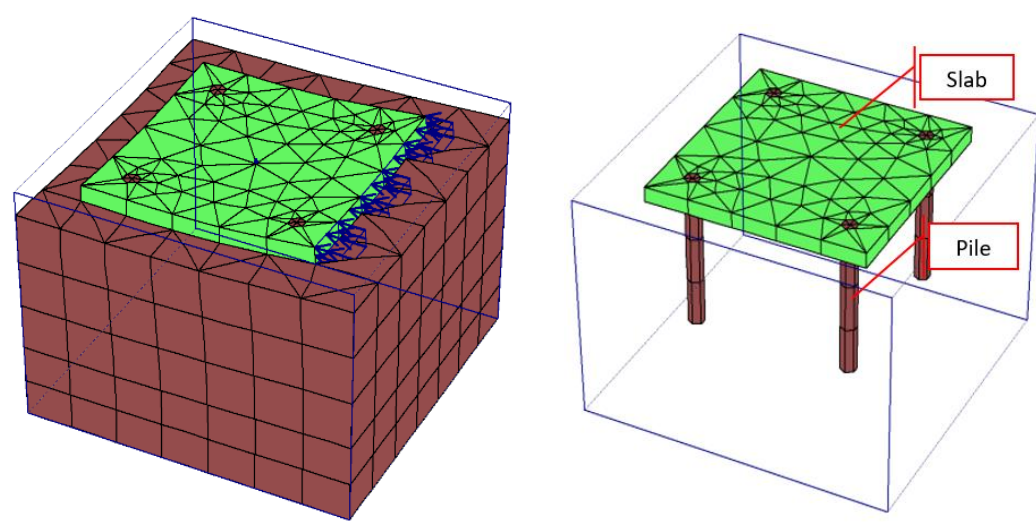

Figure 3 3D Finite Element Model

\section{RESULT AND DISCUSSION}

\subsection{Analysis of Experiment and FEM Results}

The calculation results with the finite element method as in Fig. 5 which shows that the largest deflection and for lateral loading of $4 \mathrm{kN}$ is on the middle of slab around $0.43 \mathrm{~mm}$ and $0.18 \mathrm{~mm}$ for distance $25 \mathrm{~cm}$ from end, for lateral loading $1 \mathrm{kN}$ deflection of slab around 0.32 $\mathrm{mm}$ in the middle of slab and $0.07 \mathrm{~mm}$ for distance $25 \mathrm{~cm}$ from end, meanwhile for lateral loading $2 \mathrm{kN}$ in the middle part of slab pavement $0.35 \mathrm{~mm}$ of deflection and $0.16 \mathrm{~mm}$ for distance $25 \mathrm{~cm}$ from end. When compared from the results of experimental test there are similar patterns with the results of finite element method analysis, where for loading $1 \mathrm{kN}$ deflection in the middle part $0.21 \mathrm{~mm}$ and $0.04 \mathrm{~mm}$ for distance $25 \mathrm{~cm}$ from end of slab, and latera loading $2 \mathrm{kN}$ the deflection value in the middle of the slab is $0,21 \mathrm{~mm}$ and the deflection at $25 \mathrm{~cm}$ from end of slab is $0.06 \mathrm{~mm}$, and for the lateral loading $4 \mathrm{kN}$ the deflection in the middle of the slab is $0.31 \mathrm{~mm}$ and $25 \mathrm{~cm}$ from end of slab is $0.06 \mathrm{~mm}$.

From the above results, it can be ascertained that the results of the experimental tests are still below the permissible allowances when compared from finite element method analysis match with the research of [5].

Fig. 4 shows the deformation change or ilustration deflection change of the slab in the middle and the edge of slab when applied lateral loads from finite element method analysis.

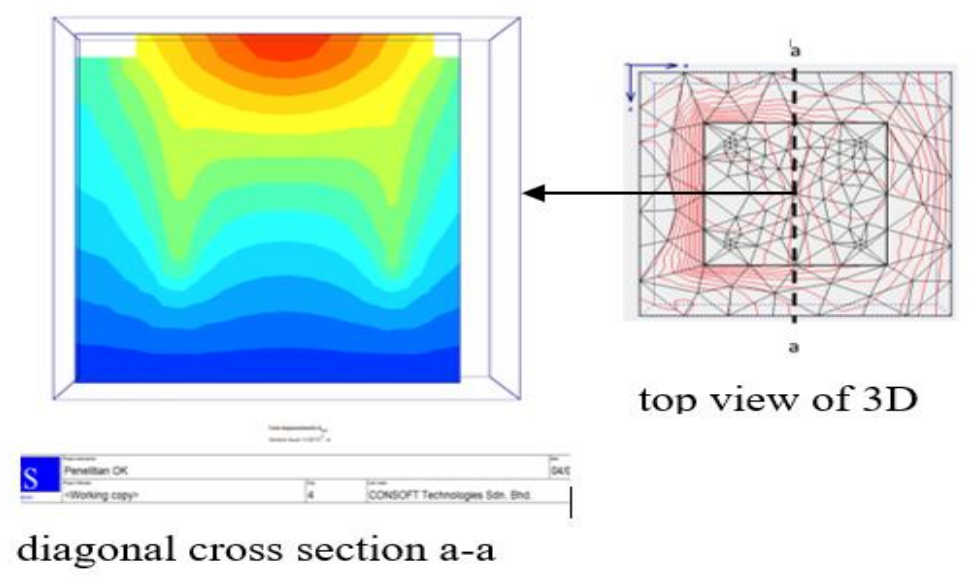




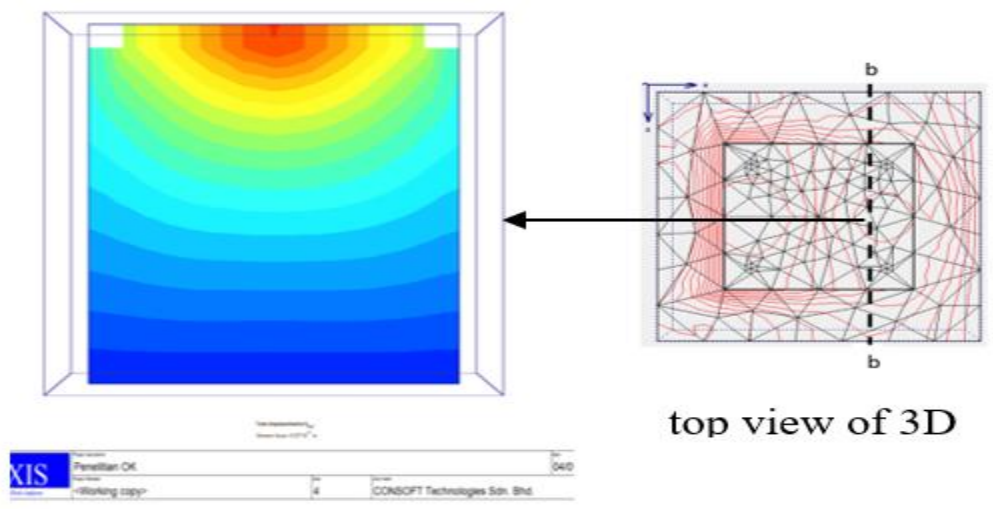

diagonal cross section $b-b$

Figure 4 Vertical Slab Deflection After Applied Loading

\subsection{Deflection of Slab}

Deflection analysis of slab pavement was conducted to determine the extent of the effect of lateral loading on the slab deflection, and this result will be compared with the results of finite element method analysis using plaxis. And the results of the analysis can be seen in Table 2 .

Table 2: Accumulative Deflection of Slab

\begin{tabular}{ccccccc}
\hline \multirow{2}{*}{$\begin{array}{c}\text { Distance of } \\
\text { Slab (m) }\end{array}$} & \multicolumn{5}{c}{ Accumulative Deflection of Slab (mm) } \\
\cline { 2 - 6 } & LL 1 kN & LL 2 kN & LL 4 kN & LL 1 kN & LL 2 kN & LL 4 kN \\
\hline 0,00 & 0,00 & 0,00 & 0,00 & 0,00 & 0,00 & 0,00 \\
0,24 & 0,04 & 0,06 & 0,06 & 0,07 & 0,16 & 0,18 \\
0,50 & 0,21 & 0,21 & 0,31 & 0,32 & 0,35 & 0,43 \\
0,75 & 0,04 & 0,06 & 0,06 & 0,07 & 0,16 & 0,18 \\
1,00 & 0,00 & 0,00 & 0,00 & 0,00 & 0,00 & 0,00 \\
\hline
\end{tabular}

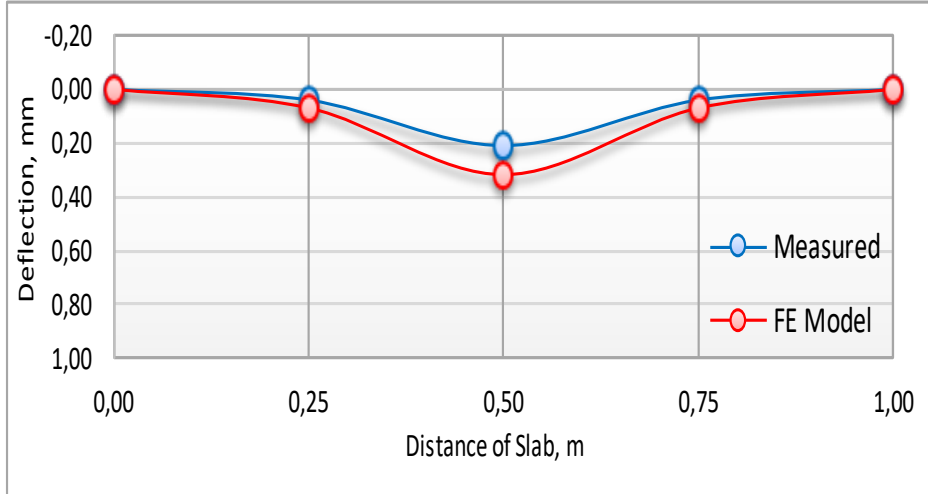

Figure 5: Deflection of Slab Measured vs FE Model LL 1 kN

Fig. 5 shows the difference between finite element method analysis and experiment test results, where the slab deflection in the middle of slab from the experiment test is $0.21 \mathrm{~mm}$ while the finite element method analysis results are $0.32 \mathrm{~mm}$. These results indicate that the finite element method results are greater when compared with the experimental results, this indicates that the experiment test results are still considered safe. 


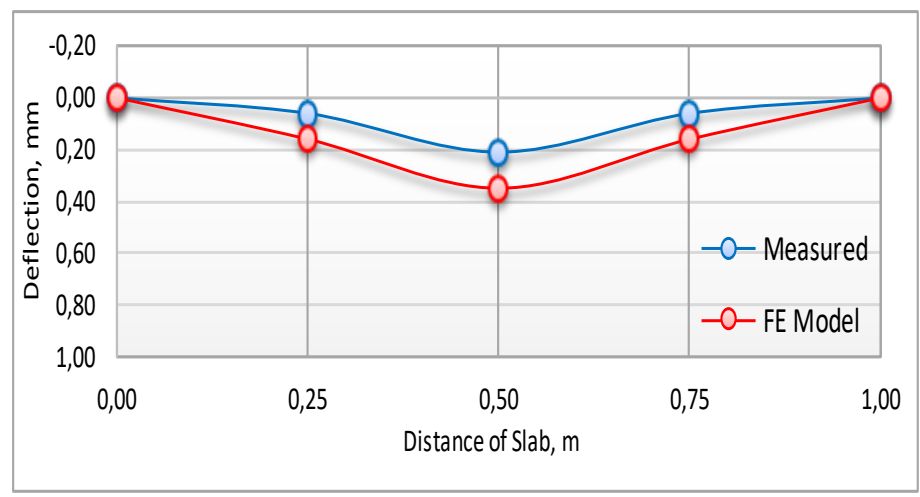

Figure 6 Deflection of Slab Measured vs FE Model LL 2 kN

Fig. 6 shows the difference between finite element method analysis and experiment test results, where the slab deflection in the middle of slab from the experiment test is $0.21 \mathrm{~mm}$ while the finite element method analysis results are $0.35 \mathrm{~mm}$. These results indicate that the finite element method results are greater when compared with the experimental results, this indicates that the experiment test results are still considered safe.

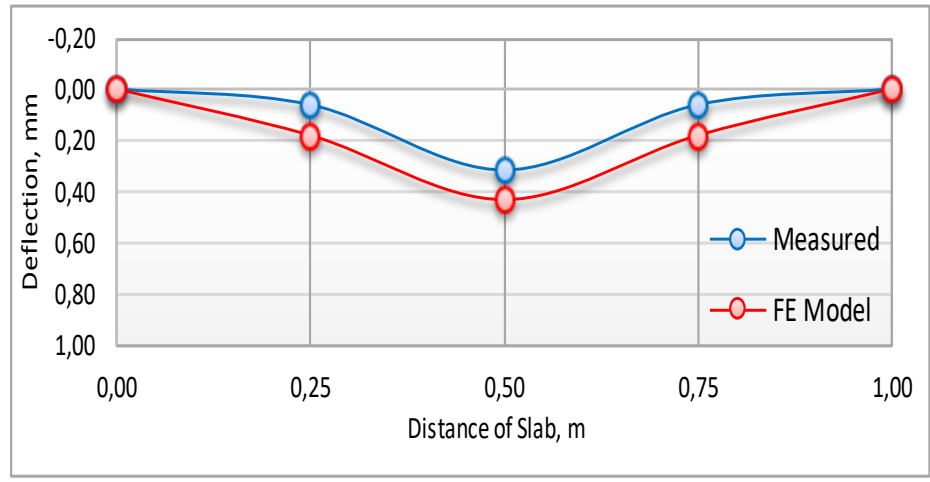

Figure 7 Deflection of Slab Measured vs FE Model LL 4 kN

Fig. 7 shows the difference between finite element method analysis and experiment test results, where the slab deflection in the middle of slab from the experiment test is $0.31 \mathrm{~mm}$ while the finite element method analysis results are $0.43 \mathrm{~mm}$. These results indicate that the finite element method results are greater when compared to the experiment test results, this indicates that the experiment test results are still considered safe.

\subsection{Deflection of Pile}

Pile deflection analysis was conducted to determine the extent of the effect of lateral loading on the pile deflection, and this result will be compared with the results of finite element method analysis using plaxis.

Table 3 Accumulative Deflection of Pile

\begin{tabular}{ccccccc}
\hline $\begin{array}{c}\text { Depth of } \\
\text { Pile } \\
(x 10 \mathrm{~mm})\end{array}$ & \multicolumn{5}{c}{ Accumulative Deformation of Pile (mm) } \\
\cline { 2 - 6 } & $\mathrm{LL} 1 \mathrm{kN}$ & $\mathrm{LL} 2 \mathrm{kN}$ & $\mathrm{LL} 4 \mathrm{kN}$ & $\mathrm{LL} 1 \mathrm{kN}$ & $\mathrm{LL} 2 \mathrm{kN}$ & $\mathrm{LL} 4 \mathrm{kN}$ \\
\hline 0 & 0,00 & 0,00 & 0,00 & 0,00 & 0,00 & 0,00 \\
40 & 0,09 & 0,24 & 0,17 & 0,11 & 0,14 & 0,48 \\
80 & 0,16 & 0,76 & 1,23 & 0,82 & 0,94 & 2,25 \\
\hline
\end{tabular}



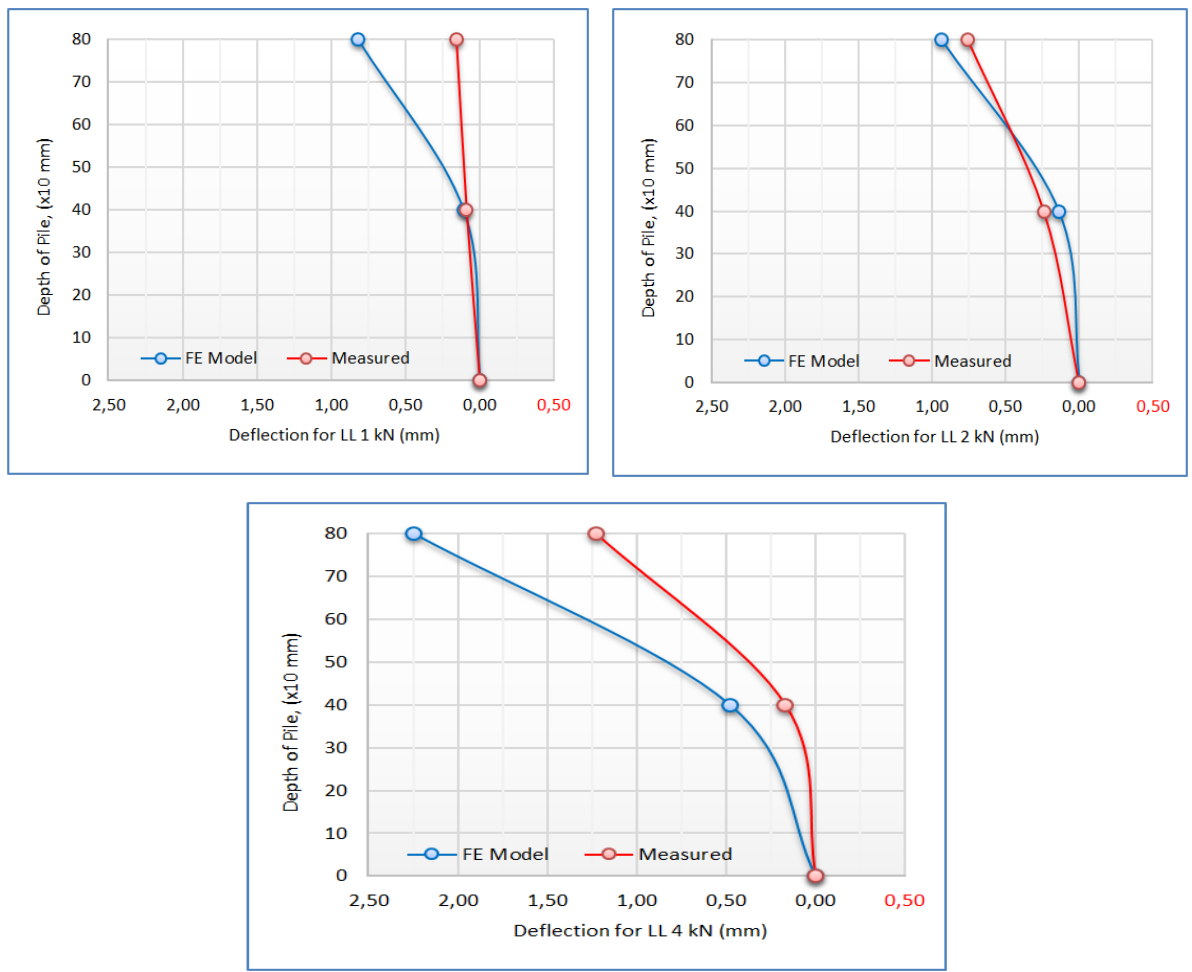

Figure 8 Pile Deflection After Applying Lateral Load

Fig. 8 is a graph of the comparison between pile defelection resulting from the experiment test and finite element method analysis for applied lateral loading of $1 \mathrm{kN}, 2 \mathrm{kN}$ and $4 \mathrm{kN}$. These results indicate that there is a similar pattern between experiment test and finite element method analysis, for lateral loading of $4 \mathrm{kN}$ deflection of top pile is $1.23 \mathrm{~mm}$ for experiment test and $2.25 \mathrm{~mm}$ for finite element method analysis. But the results from experiment deflection are still below the permissible deflection from the results of the finite element method analysis.

\section{CONCLUSIONS}

1. The lateral loading greatly affects the stability of the slab pavement with the mini pile, so it needs to be considered in carrying out the design when applied in the field.

2. The greater the lateral loading for the constant vertical loading, the greater the deflection of the resulting slab will be.

3. For maximum lateral load of up to $4 \mathrm{kN}$, slab deflection and pile deflection are still below the permit deflection.

\section{REFERENCES}

[1] Hardiyatmo, H. C. (2008). Sistem Pelat Terpaku "Nailed Slab System" Untuk Perkuatan Pelat Beton Pada Perkerasan Kaku. Seminar Nasional Teknologi Tepat Guna.

[2] A. Pratikso S. Sudarno (2019). Soil Consolidation Analysis as The Main Cause of Land Subsidence in Semarang - Indonesia. International Journal of Civil Engineering and Technology (IJCIET). 2019;10(02):793-802.

[3] Satibi, S. (2009). Numerical Analysis and Design Criteria of Embankments on Floating Piles. Disertation, Institut für Geotechnik der Universität Stuttgart. 
[4] Situmorang, A. (2017). Deflection of Rigid Pavement Nailed Slab System with Lateral Loads. Proceedings of International Conference: Problem, Solution and Development of Coastal and Delta Areas Semarang, Indonesia.

[5] Situmorang, A, Pratikso, \& Rochim, A. (2019). Settlement of nailed slab due to lateral loads. IOP Conference Series: Materials Science and Engineering, 527, 012024. doi: $10.1088 / 1757-899 x / 527 / 1 / 012024$ 